\title{
Low grazing impact of mesozooplankton on the microbial communities of the Alboran Sea: a possible case of inhibitory effects by the toxic dinoflagellate Gymnodinium catenatum
}

\author{
Albert Calbet*, Elisabetta Broglio, Enric Saiz, Miquel Alcaraz \\ Institut de Ciències del Mar, CMIMA (CSIC), Departament de Biologia Marina i Oceanografia, \\ P. Marítim de la Barceloneta 37-49, 08003 Barcelona, Catalunya, Spain
}

\begin{abstract}
The grazing impact of the mesozooplankton community on algae and protozoans was assessed during September 1999 in the Alboran Sea (SW Mediterranean). Ingestion rates were obtained by incubating aliquots of net-collected mesozooplankton with natural seawater. The results showed a weak pressure of mesozooplankton on algae and protozoans, with grazing impacts on community stocks averaging 1.3, 1.4 and $1.5 \%$ for phytoplankton, ciliates and dinoflagellates, respectively. Chlorophyll $a$ (chl a) $>5 \mu \mathrm{m}$ was grazed at higher rates than chl $a<5 \mu \mathrm{m}$, and in some stations dinoflagellates were preferred over ciliates. In general, ingestion rates were low, yielding to daily rations ranging from 2 to $20 \%$ of body carbon, which were too low to cover the metabolic demand of mesozooplankton in most of the stations. We hypothesize that this unexpected result could be in relation to the presence of the toxic dinoflagellate Gymnodinium catenatum in the study area.
\end{abstract}

KEY WORDS: Mesozooplankton · Phytoplankton · Ciliates · Dinoflagellates · Gymnodinium catenatum $\cdot$ Ingestion $\cdot$ Grazing $\cdot$ Alboran Sea

Resale or republication not permitted without written consent of the publisher

\section{INTRODUCTION}

In most of the research on the functional role of mesozooplankton $(0.2$ to $20 \mathrm{~mm}$ ) in marine food webs, herbivory has been considered to be the main path of transfer of organic matter from primary producers to higher trophic levels. As a result, the majority of studies on zooplankton feeding have largely used the gut fluorescence technique to estimate zooplankton grazing impact (see review by Calbet 2001). Because this technique uses photosynthetic pigments to estimate food intake, the contribution of microzooplankton to the diet is systematically ignored. An increasing number of studies, however, have shown non-autotrophic food sources to be important contributors to the diet as well (see review by Sanders \& Wickham 1993). This is particularly the case for planktonic ciliates and

*E-mail: acalbet@icm.csic.es heterotrophic dinoflagellates (Fessenden \& Cowles 1994, Nakamura \& Turner 1997, Lonsdale et al. 2000), both key agents in the functioning of microbial food webs (Sherr et al. 1986, Sherr \& Sherr 1988). By grazing upon protozoans, zooplankton may benefit from supplementary food sources and complement the diet with additional essential nutrients needed for metabolism (Kleppel \& Burkart 1995, Klein Breteler et al. 1999). However, there is also evidence of deleterious effects on zooplankton feeding or fecundity due to heterotrophic dinoflagellates (Stoecker \& Sanders 1985) and ciliates (Ederington et al. 1995). The scenario becomes more complex when species-specific toxic effects of certain dinoflagellates are considered (Turriff et al. 1995, Turner \& Tester 1997, Delgado \& Alcaraz 1999, Teegarden 1999). It seems, thus, that the relationships between zooplankton and the different components of the microbial community are important but highly specific, very variable and difficult to predict. 
However, and in spite of the relevance of microzooplanktonic organisms as food for mesozooplankton, relatively few studies consider both algal and animal food sources when assessing the impact of mesozooplankton grazing in natural communities. Among those, even fewer take into consideration the whole mesozooplanktonic community instead of single copepod species (e.g., Carrick et al. 1991, Calbet \& Landry 1999, Thouvenot et al. 1999). Here, we present a community grazing approach to study the dynamics and relationships between the different compartments of microplankton and mesozooplankton in a marine pelagic community. The study took place in the Alboran Sea (SW Mediterranean), a highly dynamic area (Jiménez et al. 1987, Minas et al. 1991, Rodríguez et al. 1998) characterized by the presence of a persistent anticyclonic gyre caused by the inflow of Atlantic waters into the Mediterranean basin through the Strait of Gibraltar (Minas et al. 1991, Tintoré et al. 1991). The gyre is associated with a frontal zone in which intermittent upwelling of nutrient rich waters (Coste et al. 1988, Perkins et al. 1990, Minas et al. 1991) produces sporadic phytoplankton blooms (Videau et al. 1994). The Alboran Sea provides, thus, an excellent scenario for our purposes because in a relatively small area mesozooplankton can potentially experience a wide spectrum of different trophic conditions.

\section{METHODS}

Sampling strategy. The study was conducted on board the RV 'Hespérides' from 14 to 24 September 1999 in the Alboran Sea (SW Mediterranean). Sampling took place around noon at 3 fixed stations $(\mathrm{A}, \mathrm{B}$ and $\mathrm{C}$, respectively at $36^{\circ} 23^{\prime} \mathrm{N}, 4^{\circ} 15^{\prime} \mathrm{W} ; 36^{\circ} 14^{\prime} \mathrm{N}$, $4^{\circ} 15^{\prime} \mathrm{W}$; and $36^{\circ} 0^{\prime} \mathrm{N}, 4^{\circ} 15^{\prime} \mathrm{W}$; Fig. 1) located along a transect crossing the northern part of the Western Alboran Gyre. Stn A was visited 2 times (A1 and A2); and Stns B and C were visited 3 (B1, B2 and B3) and 2 (C1 and C3) times, respectively. Previous studies (Morán \& Estrada 2001) reported Stn A as representative of upwelling conditions, while Stns B and C were expected to be more oligotrophic. The hydrographic characteristics and fluorescence profiles of the surveyed stations were determined by conductivity, temperature, density (CTD) casts made with a Neil-Brown MARK-V CTD equipped with a Sea Tech fluorometer. Water samples for chlorophyll a ( $\mathrm{chl} \mathrm{a}$ ) analyses and for microplankton profiles (0 to $100 \mathrm{~m}$ ) were collected at 10 to $20 \mathrm{~m}$ depth intervals using a rosette provided with 121 Niskin bottles. For total chl a, $100 \mathrm{ml}$ of water was filtered under low vacuum pressure (<100 mm Hg) through Whatman glass fiber filters (GF/F, $25 \mathrm{~mm}$ diameter). For the $>5 \mu \mathrm{m}$ fraction, $200 \mathrm{ml}$ samples were

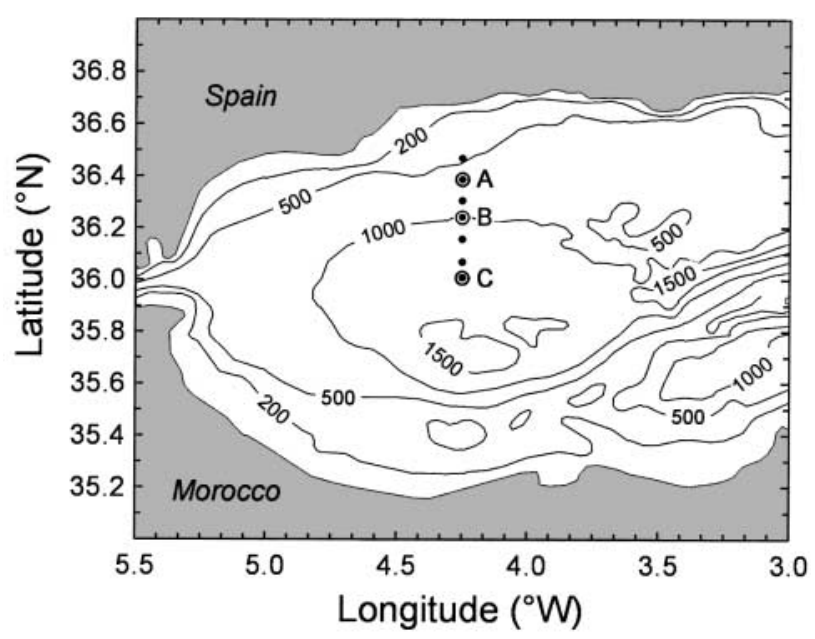

Fig. 1. Map of the area surveyed showing the location of the 3 main stations (Stns A, B and C)

filtered through $5 \mu \mathrm{m}$ pore-size polycarbonate Nucleopore $^{\mathrm{TM}}$ filters (25 mm diameter). After filtration, the filters were stored frozen at $-80^{\circ} \mathrm{C}$ until analysis (see below). Water samples for the determination of microplankton abundance were fixed with $1 \%$ Lugol's solution (Leaky et al. 1994).

Samples for mesozooplankton biomass and abundance quantification were obtained from 200 to $0 \mathrm{~m}$ vertical plankton tows made with a $57 \mathrm{~cm}$ diameter double WP-2 net (200 $\mu \mathrm{m}$ mesh) without flowmeter, towed at $30 \mathrm{~m} \mathrm{~min}^{-1}$. One of the cod ends was entirely preserved with buffered formalin (5\% final solution) for later assessment of community composition. The contents of the other cod end was poured into a graduated cylinder from which 3 aliquots of $10 \mathrm{ml}$ each were taken after thorough mixing, filtered onto GF/F glass fiber filters, quickly washed with ammonium formiate and dried at $60^{\circ} \mathrm{C}$ for later measurement of zooplankton community dry weight (DW). In order to minimize organismal damage due to the net tow process, the mesozooplankton samples for grazing experiments were obtained with a similar protocol, but with shallower (up to $75 \mathrm{~m}$ depth) and slower $\left(10 \mathrm{~m} \mathrm{~min}^{-1}\right)$ net tows. A 41 plastic bag was used instead of the closed cod end to reduce sampling stress and damage. These shallower tows integrated the depth of highest organismal abundance (Sabatés et al. unpubl.).

Experimental design. Experimental water for grazing assessment was collected at the depth of the chl a maximum using 501 Van Dorn-type transparent bottles. The water was gently poured into a 501 bucket and reverse-flow filtered by gently submerging a $30 \mathrm{~cm}$ diameter polyvinyl chloride (PVC) cylinder with a bottom of $100 \mu \mathrm{m}$ mesh. By this procedure we eliminated $>100 \mu \mathrm{m}$ metazoan predators from the water 
inside the sieve, while only a few rarely abundant large phytoplankton cells were excluded (Rodríguez et al. 1998). Once the suspension was ready it was amended with a nutrient mixture $\left(15 \mu \mathrm{M} \mathrm{NH}{ }_{4} \mathrm{Cl}\right.$ and $1 \mu \mathrm{M} \mathrm{Na}_{2} \mathrm{HPO}_{4}$ ) to compensate for nutrient enrichment due to zooplankton excretion, and the experimental water was left from 15 to 20 min to allow the microplanktonic community to stabilize. After this period of time, 6 transparent wide-mouth polyethylene bottles of 51 capacity were gently filled with the water from inside the sieve. Three of them were used as controls; in the other 3 an aliquot of $10 \mathrm{ml}$ of a total volume of $500 \mathrm{ml}$ of concentrated suspension containing mesozooplankton from the net tow was added. Duplicate initial samples were taken for microplankton and chl a quantification as described previously, and 4 extra mesozooplankton initial aliquots were filtered onto GF/F glass filters and dried for assessment of biomass (DW). The bottles were incubated for $24 \mathrm{~h}$ in an incubator cooled with circulating surface seawater (temperature 16.0 to $16.5^{\circ} \mathrm{C}$ ) and light screened with a dark mesh that filtered $99 \%$ of the surface light intensity. The incubation bottles were gently turned upside down several times during the incubations to reduce settling of algae.

Sample analysis. Mesozooplankton abundance and species composition were estimated by counting and identifying under stereomicroscope at least 300 ind. sample $^{-1}$. Chl a was fluorometrically analyzed according to Yentsch \& Menzel (1963). Frozen filters were placed in $6 \mathrm{ml}$ of $90 \%$ acetone and kept for ca $24 \mathrm{~h}$ in the dark at $4^{\circ} \mathrm{C}$. Fluorescence was subsequently measured without acidification with a Turner Designs fluorometer. For microplankton abundance assessment, preserved $100 \mathrm{ml}$ samples were settled in Utermöhl settling chambers for $48 \mathrm{~h}$ and counted under a Zeiss Axiovert 35 microscope. Ciliate abundance was corrected by a factor of losses due to $1 \%$ Lugol's fixation of $25 \%$ (Broglio et al. unpubl.). Video images of 50 random dinoflagellates and 50 ciliates sample ${ }^{-1}$ were digitized with a Power Macintosh computer provided with a frame grabber and NIH Image (National Institutes of Health, Bethesda, MD, USA) analysis software. The contour of the organisms was outlined, the area was measured, and the length and width of the cell were automatically estimated assuming an ellipsoidal shape.

Microplankton biovolumes were converted to cell carbon using a factor of $0.19 \mathrm{pg} \mathrm{C} \mathrm{\mu m}^{-3}$ for ciliates (Putt $\&$ Stoecker 1989) and the equation $\log \mathrm{pgC} \mathrm{cell}^{-1}=$ $-0.119+(0.819 \log$ volume $)$ for dinoflagellates (Menden-Deuer \& Lessard 2000). Zooplankton carbon contents was considered to be $45 \%$ DW (Omori \& Ikeda 1984). Chlorophyll concentration was transformed into phytoplankton carbon using a carbon-to- chlorophyll ratio of 25 for Stns A and B, and 60 for Stn C. These ratios corresponded to those used in a previous cruise (May 1998) and were calculated by combining fluorimetrical measurements of chlorophyll with microscopic biovolumetric estimations and later converted to carbon using literature values (Arin et al. unpubl.). Ingestion rates were calculated according to the equations of Frost (1972).

\section{RESULTS}

\section{Environmental conditions}

\section{Horizontal distribution}

The different stations could not be characterized by persistent patterns of integrated abundance or biomass of the different plankton groups (Tables $1 \& 2$ ). The stations showed important differences among the consecutive visits, so the expected positive abundance gradient from upwelling stations (Stn A) to the more oceanic ones (Stns B and C) was masked by temporal variability and by a possible displacement of upwelled waters toward the open ocean. Only during the last visit to Stn C (C3) were the chl a values similar to those expected for oceanic oligotrophic waters (Moran \& Estrada 2001). Surprisingly, chl a concentrations reached the highest values at Stns B3 and C1. Phytoplankton dominated the biomass of the planktonic community, followed in relevance by mesozooplankton. Among the 2 size-fractions of chl $a$, the biomass of $>5 \mu \mathrm{m}$ autotrophs was, in general, similar to or greater than the smaller size-classes (except for Stn C3). The contribution of $>5 \mu \mathrm{m}$ to total $\mathrm{chl}$ a showed a consistent, albeit not significant, tendency to increase with total chl a concentration $(r=0.6$, $p=0.12$ ), even if the range of the contribution percentage was narrow ( 40 to $68 \%$ ).

Ciliates were more abundant than dinoflagellates, except at Stn C3, where the toxic dinoflagellate Gymnodinium catenatum contributed in great measure to an increase in the total dinoflagellate abundance (Table 1). G. catenatum, which was detected in all the stations, showed a negative relationship with chl a distribution $(\mathrm{r}=0.86, \mathrm{p}<0.02)$. Both ciliates and dinoflagellates represented from 6 to $35 \%$ of the total planktonic community biomass.

The horizontal distribution of mesozooplankton across the transect did not correspond either with the expected higher abundance at coastal stations (Tables 1 \& 2). Instead, the maximum values were found at Stn B2. The community was numerically dominated by copepods and cladocerans (Table 3). The bulk of the copepod community corresponded to an assemblage of copepodite stages of calanoids (Clauso- 
Table 1. Integrated values of chlorophyll a ( $\mathrm{chl}$ a) concentration, and abundance of ciliates, dinoflagellates (0 to $100 \mathrm{~m})$ and mesozooplankton (0-200 m) for the consecutive visits at the 3 fixed stations (Stns A, B and C). The abundance of the dinoflagellate Gymnodinium catenatum is also presented individually because of its implications in the study (see 'Discussion')

\begin{tabular}{|c|c|c|c|c|c|c|c|}
\hline & $\begin{array}{l}\text { Stn A1 } \\
15 \text { Sep }\end{array}$ & $\begin{array}{l}\text { Stn A2 } \\
21 \text { Sep }\end{array}$ & $\begin{array}{l}\text { Stn B1 } \\
16 \text { Sep }\end{array}$ & $\begin{array}{l}\text { Stn B2 } \\
20 \text { Sep }\end{array}$ & $\begin{array}{l}\text { Stn B3 } \\
23 \text { Sep }\end{array}$ & $\begin{array}{l}\text { Stn C1 } \\
17 \text { Sep }\end{array}$ & $\begin{array}{l}\text { Stn C3 } \\
22 \text { Sep }\end{array}$ \\
\hline $\begin{array}{l}\text { Chl } a>5 \mu \mathrm{m} \\
\left(\mathrm{mg} \mathrm{chl} a \mathrm{~m}^{-2}\right)\end{array}$ & 46.4 & 31.6 & 67.3 & 60.4 & 66.3 & 68.1 & 13.3 \\
\hline $\begin{array}{l}\text { Chl } a<5 \mu \mathrm{m} \\
\left(\mathrm{mg} \mathrm{chl} a \mathrm{~m}^{-2}\right)\end{array}$ & 48.9 & 32.6 & 31.2 & 28.5 & 52.3 & 46.4 & 20.4 \\
\hline $\begin{array}{l}\text { Ciliates } \\
\left(\text { cells m }{ }^{-2}\right)\end{array}$ & $4.3 \times 10^{8}$ & $4.7 \times 10^{8}$ & $2.1 \times 10^{8}$ & $3.8 \times 10^{8}$ & $3.9 \times 10^{8}$ & $3.3 \times 10^{8}$ & $1.8 \times 10^{8}$ \\
\hline $\begin{array}{l}\text { Dinoflagellates } \\
\left(\text { cells m }{ }^{-2} \text { ) }\right.\end{array}$ & $3.3 \times 10^{8}$ & $2.2 \times 10^{8}$ & $2.1 \times 10^{8}$ & $2.0 \times 10^{8}$ & $1.8 \times 10^{8}$ & $2.3 \times 10^{8}$ & $2.8 \times 10^{8}$ \\
\hline $\begin{array}{l}\text { G. catenatum } \\
\left(\text { cells } \mathrm{m}^{-2}\right)\end{array}$ & $5.4 \times 10^{7}$ & $2.8 \times 10^{7}$ & $2.6 \times 10^{7}$ & $1.7 \times 10^{7}$ & $2.0 \times 10^{6}$ & $4.0 \times 10^{6}$ & $1.3 \times 10^{8}$ \\
\hline $\begin{array}{l}\text { Mesozooplankton } \\
\left(\text { ind. } \mathrm{m}^{-2} \text { ) }\right.\end{array}$ & 348039 & 223039 & 409804 & 552941 & 185784 & 210294 & 177451 \\
\hline
\end{tabular}

Table 2. Integrated values of chl $a$, ciliates, dinoflagellates ( 0 to $100 \mathrm{~m}$ ) and mesozooplankton ( 0 to $200 \mathrm{~m}$ ) carbon concentration

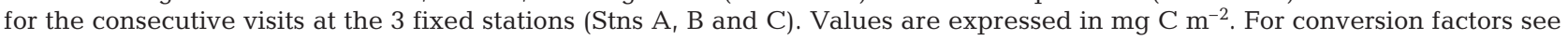
text ('Methods' section)

\begin{tabular}{|c|c|c|c|c|c|c|c|}
\hline & Stn A1 & Stn A2 & Stn B1 & Stn B2 & Stn B3 & Stn C1 & Stn C3 \\
\hline Chl $a>5 \mu \mathrm{m}$ & 1160.0 & 790.0 & 1682.5 & 1510 & 1657.5 & 4086.0 & 798.0 \\
\hline Chl $a<5 \mu \mathrm{m}$ & 1222.5 & 815.0 & 780.0 & 712.5 & 1307.5 & 2784.0 & 1224.0 \\
\hline Ciliates & 688.0 & 914.8 & 402.4 & 499.2 & 892.4 & 330.0 & 128.8 \\
\hline Dinoflagellates & 464.8 & 324.0 & 332.8 & 159.2 & 141.6 & 136.8 & 330.0 \\
\hline Mesozooplankton & 1379.8 & 672.3 & 1328 & 1732.3 & 657.6 & 901.9 & 1224.1 \\
\hline
\end{tabular}

Table 3. Zooplankton community major groups for the consecutive visits at the 3 fixed stations (Stns A, B and C). Values are expressed in ind. $\mathrm{m}^{-2}$

\begin{tabular}{|c|c|c|c|c|c|c|c|}
\hline Taxon & Stn A1 & Stn A2 & Stn B1 & Stn B2 & Stn B3 & Stn C1 & Stn C3 \\
\hline Copepods & 187255 & 86765 & 172549 & 287255 & 130392 & 123529 & 98529 \\
\hline Cladocerans & 119608 & 105392 & 217647 & 220588 & 21078 & 58333 & 44608 \\
\hline Ostracods & 9804 & 6863 & 3922 & 12745 & 15686 & 3431 & 3922 \\
\hline Crustacean larvae & 3922 & 3922 & 1961 & 6863 & 1471 & 9314 & 4412 \\
\hline Cnidarians & 5882 & 1961 & 980 & 4902 & 4412 & 1471 & 1961 \\
\hline Chaetognaths & 7843 & 1961 & 1961 & 2941 & 1961 & 3922 & 6373 \\
\hline Appendicularians & 4902 & 8333 & 7843 & 5882 & 4902 & 6373 & 5392 \\
\hline Other tunicates & 5882 & 1961 & 980 & 0 & 3431 & 1471 & 490 \\
\hline Equinoderm larvae & 0 & 0 & 0 & 3922 & 0 & 0 & 490 \\
\hline Molluscs & 2941 & 5882 & 1961 & 7843 & 2451 & 2451 & 11275 \\
\hline
\end{tabular}

calanus spp., Calocalanus spp., Paracalanus spp. and Ctenocalanus spp.), and, of minor importance, Oithona spp. and Centropages typicus; among Cladocerans, Penilia avirostris was the dominant species (Table 4). The copepod/cladoceran quotients ranged between 0.8 and 2.2, except at Stn B3, where it was 6.2. Other remarkable features of the zooplanktonic community during the study were the ubiquitous presence of appendicularians and molluscs (mostly pteropods), and a sporadic bloom of echinoderm larvae at Stn B2. Larger predators, such as chaetognaths and cnidarians, were also present at all stations, although their abundances never reached values above 800 ind. $\mathrm{m}^{-2}$. No significant correlation was observed between inte- 
Table 4. Species composition in ind. $\mathrm{m}^{-2}$ of the copepod and cladoceran communities at the stations surveyed. The group 'calanoida copepodites' includes juveniles of the genera Clausocalanus, Paracalanus, Ctenocalanus and Calocalanus, which were considered together due to morphological resemblance. For the rest of copepods the data shown correspond to adults plus copepodites

\begin{tabular}{|c|c|c|c|c|c|c|c|}
\hline Species & Stn A1 & Stn A2 & Stn B1 & Stn B2 & Stn B3 & Stn C1 & Stn C3 \\
\hline \multicolumn{8}{|l|}{ Copepods } \\
\hline Clausocalanus spp. & 13725 & 5882 & 7843 & 15686 & 5392 & 5882 & 11275 \\
\hline Paracalanus parvus & 7843 & 2941 & 12745 & 3922 & 7353 & 5392 & 1471 \\
\hline Ctenocalanus vanus & 6863 & 490 & 980 & 0 & 490 & 490 & 1471 \\
\hline Calocalanus spp. & 12745 & 4902 & 6863 & 5882 & 4902 & 3431 & 6373 \\
\hline Calanoida copepodites & 48039 & 19608 & 51961 & 48039 & 50000 & 24510 & 24020 \\
\hline Centropages typicus & 10784 & 4902 & 25490 & 10784 & 12255 & 17647 & 3922 \\
\hline Temora stylifera & 6863 & 4412 & 18627 & 5882 & 3922 & 8824 & 5392 \\
\hline Eucalanus spp. & 3922 & 7353 & 8824 & 22549 & 1471 & 16667 & 980 \\
\hline Acartia spp. & 7843 & 7843 & 6863 & 23529 & 4412 & 4412 & 8333 \\
\hline Euterpina acutifrons & 4902 & 980 & 0 & 8824 & 0 & 2941 & 490 \\
\hline Oithona spp. & 23529 & 19118 & 19608 & 27451 & 21569 & 7353 & 11765 \\
\hline Oncaea spp. & 21569 & 2451 & 5882 & 11765 & 5882 & 6373 & 7843 \\
\hline Corycaeus spp. & 3922 & 980 & 980 & 2941 & 490 & 490 & 7843 \\
\hline Other copepods & 14706 & 3922 & 5882 & 20588 & 11275 & 9804 & 6373 \\
\hline \multicolumn{8}{|l|}{ Cladocerans } \\
\hline Penilia avirostris & 95098 & 94608 & 191176 & 208824 & 19118 & 53431 & 30392 \\
\hline Evadne spp. & 24510 & 10784 & 26471 & 11765 & 1961 & 4902 & 14216 \\
\hline
\end{tabular}

grated mesozooplankton biomass or abundance and their possible prey (chl a, ciliates or dinoflagellates).

\section{Vertical distribution}

The mixed layer extended to the first 20 to $30 \mathrm{~m}$ depth at all the surveyed stations, being less conspicuous at the more oceanic ones (Fig. 2). In general, the chl a maximum was situated below the thermocline, between 20 and $40 \mathrm{~m}$ depth, except at Stns B3 and C3, where the higher values were found at surface layers (Fig. 3). In general, the vertical distribution of chl a approximately paired the profiles of dinoflagellates and ciliates, except at Stn B1 (Fig. 4). Ciliate and dinoflagellate maxima coincided in depth, with ciliates more abundant than flagellates at that layer. The exception to the later was Stn C3, mostly due to the high abundance of Gymnodinium catenatum between 20 and $40 \mathrm{~m}$ (data not shown).

\section{Feeding rates and mesozooplankton grazing impact}

Weight-specific ingestion rates of the mesozooplanktonic community on the different fractions of chl a are shown in Fig. 5. In general, ingestion rates were low $\left(<1.5 \mathrm{mg}\right.$ chl a mg DW $\left.{ }^{-1} \mathrm{~d}^{-1}\right)$, with the highest values found at Stns B3 and C1. Grazing was higher on $>5 \mu \mathrm{m}$ fractions ( $p<0.05$, analysis of variance [ANOVA]), except for Stn A1. Ingestion rates on chl a size- fractions were significantly ( $\mathrm{p}<0.05$ ), although poorly correlated with pigment concentration (Fig. 6). No significant differences were found between the regression lines describing the relationship between chl a ingestion and the concentration of the different sizefractions (analysis of covariance [ANCOVA]), indicating that the feeding response to algal food concentration was proportional to the different size-fractions considered. The impact that mesozooplankton feeding was exerting on chl a standing stock was also low, averaging $1.3 \%$ for all stations and ranging form 0.3 for Stn B1 to 2.4 for Stn C1.

The weight-specific ingestion rates on ciliates and dinoflagellates by mesozooplankton are shown in Fig. 7 . For ciliates, as for chl $a$, the highest grazing rates occurred at Stn B3. On the other hand, Stn C1, the second station in importance in terms of chl a ingestion, presented the minimum grazing rates upon ciliates. Specific ingestion rates on ciliates were directly related to their concentration (Fig. 8). However, specific feeding on dinoflagellates was very constant during the study and independent of cell concentration, ranging from 1000 to 2500 dinoflagellate cells $\mathrm{mg} \mathrm{DW}^{-1} \mathrm{~d}^{-1}$ at Stns C3 and A1, respectively (Fig. 8). Total grazing impact on microplankton communities was low, averaging $1.4 \%$ (range 0.3 to $3.5 \%$ ) and $1.5 \%$ (range 0.8 to $2.3 \%$ ) for ciliates and dinoflagellates, respectively.

Overall, feeding on phytoplankton and microplankton (ciliates and dinoflagellates) accounted for $<5 \%$ of mesozooplankton body carbon in most of the stations (Fig. 9). The contribution of chl a to the mesozooplank- 

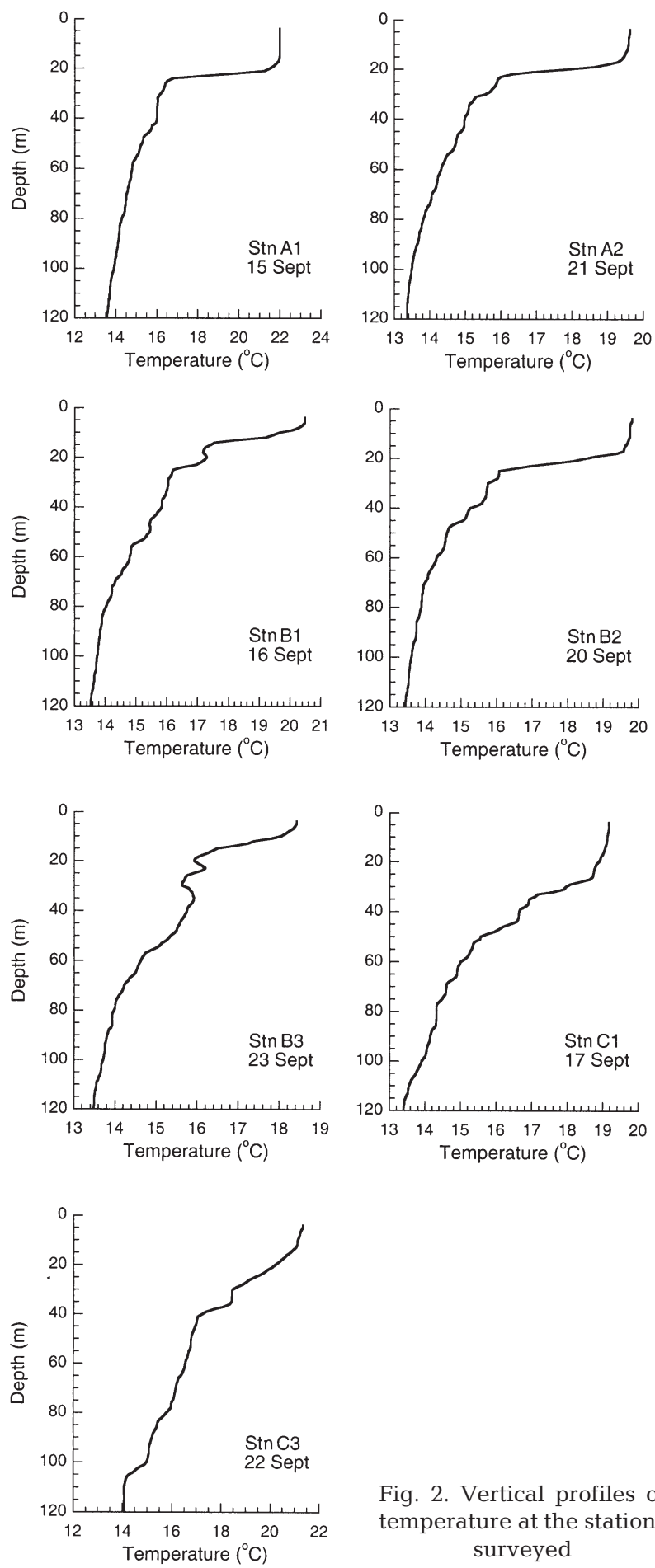

Fig. 2. Vertical profiles of temperature at the stations surveyed
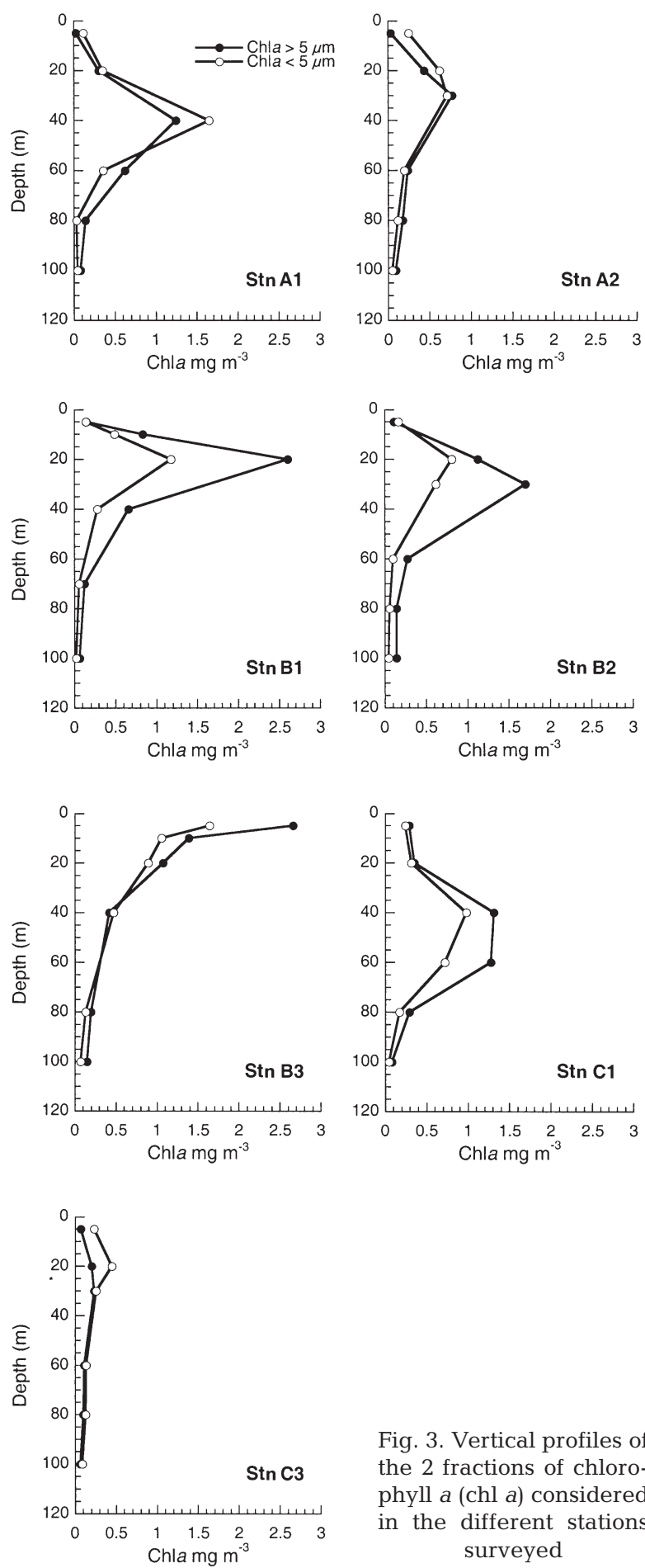

Fig. 3. Vertical profiles of the 2 fractions of chlorophyll a (chl a) considered in the different stations surveyed ton diet ranged from 26 to $99 \%$ of total ingested carbon; ciliates represented from 0.4 to $49 \%$, and dinoflagellates accounted for $<25 \%$. Since the technique used to preserve microplankton did not allow for differentiation between autotrophy and heterotrophy, part of the contribution of dinoflagellates to the daily rations was already considered in terms of chl a. Nevertheless, due to the notoriously higher contribution of autotrophic food in the diet, no attempt was made to correct the data.

Between the 2 fractions of chl a considered, mesozooplankton showed higher proportional ingestion rates on 

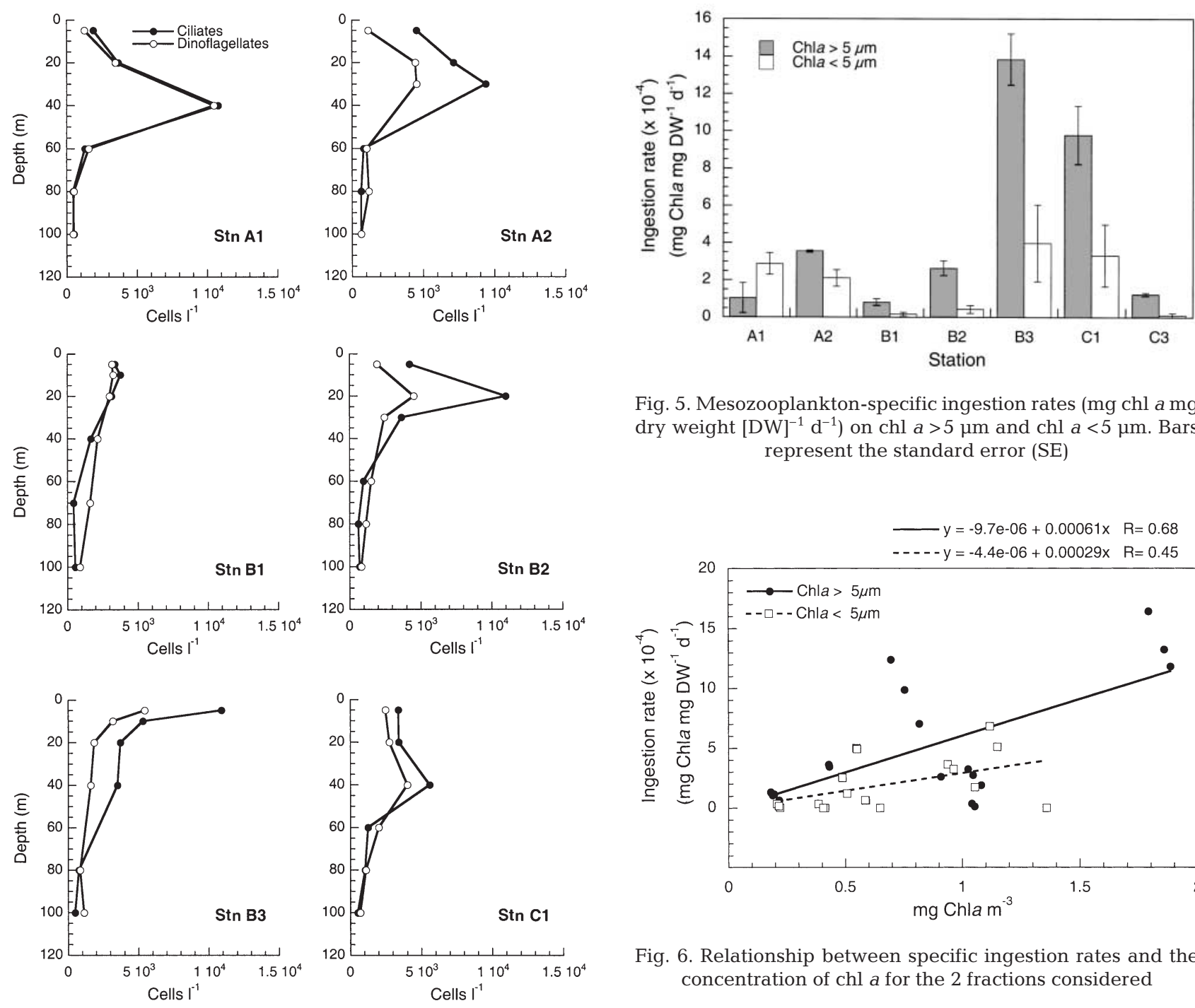

Fig. 5. Mesozooplankton-specific ingestion rates (mg chl a mg dry weight $[\mathrm{DW}]^{-1} \mathrm{~d}^{-1}$ ) on chl $a>5 \mu \mathrm{m}$ and chl $a<5 \mu \mathrm{m}$. Bars represent the standard error (SE)

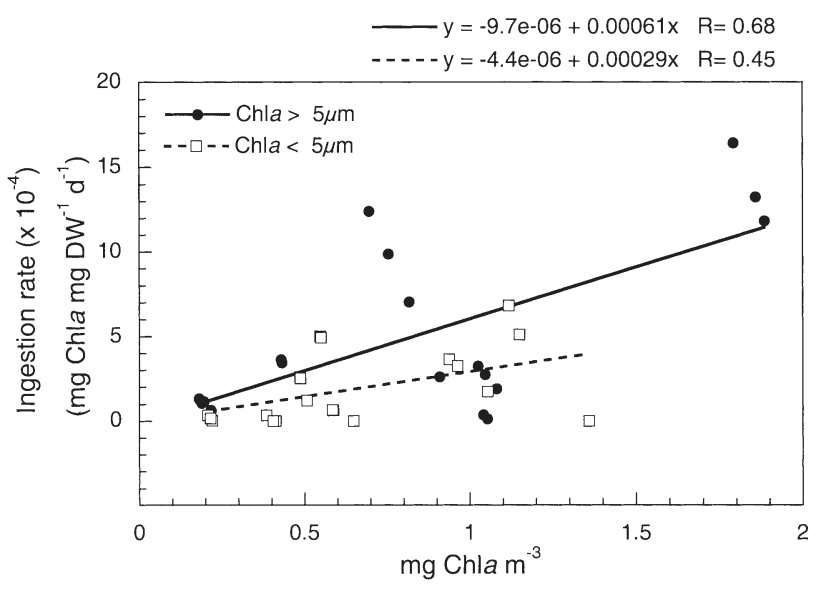

Fig. 6. Relationship between specific ingestion rates and the concentration of chl a for the 2 fractions considered

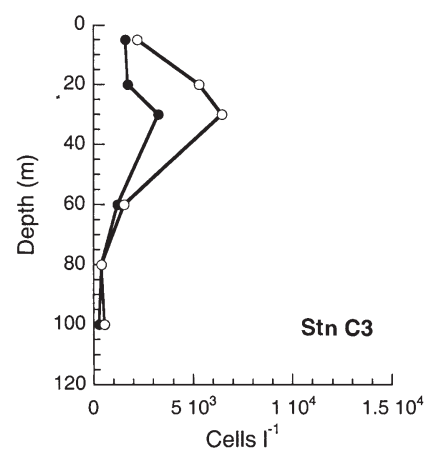

Fig. 4. Vertical profiles of ciliates and dinoflagellates in the different stations surveyed

cells larger than $5 \mu \mathrm{m}$, with a few exceptions corresponding to single replicate bottles in Stns A1, C1 and C3 (Fig. 10). When ciliates and dinoflagellates were compared, a tendency toward selecting dinoflagellates was observed, especially at Stns A1 and C1 (Fig. 10). However, in the rest of stations no clearly conclusive pattern was observed.

\section{DISCUSSION}

Due to the complex hydrodynamics of the Alboran Sea (Jiménez et al. 1987, Minas et al. 1991, Rodríguez et al. 1998) any spatial trend in the abundance of the planktonic groups here considered was masked by temporal variability. In spite of this very variable environment, the estimates of phyto- and mesozooplankton biomass fall within the range of values reported in previous studies in adjacent areas of the Alboran Sea (García \& Camiñas 1985, Jiménez et al. 1987, Thibault et al. 1994, Moran \& Estrada 2001). Thus, the lack of clear correlations between integrated mesozooplankton biomass and chl a concentration could be indicative of an uncoupling between consumers and producers, typical of highly dynamic systems. In such systems the response of the zooplanktonic community cannot cope with the frequency of environmental changes 

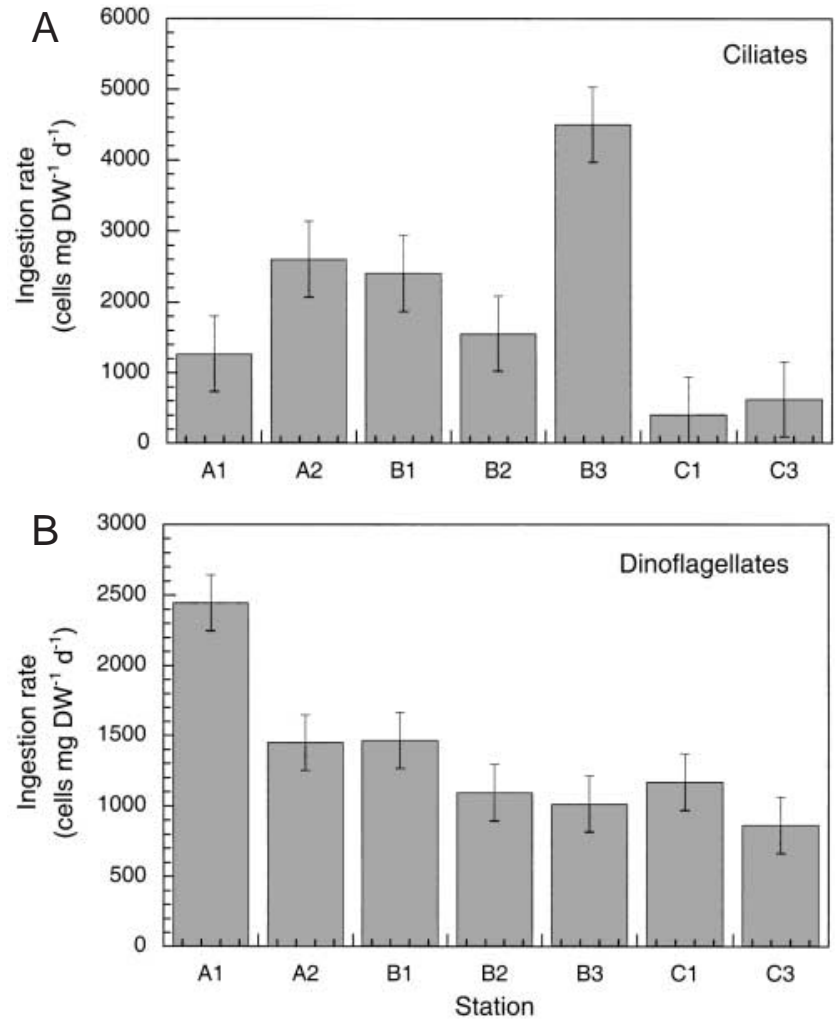

Fig. 7. Mesozooplankton-specific ingestion rates on (A) ciliates and (B) dinoflagellates for the different stations surveyed. Bars represent SE

(Calbet et al. 1996). This uncoupling could be the possible cause of the peculiar community biomass distribution of the different groups in the planktonic community. Conceptually, one would expect that under upwelling conditions, or in productive coastal environments, large phytoplankton and zooplankton would dominate the community biomass, which was not the case for the coastal stations (A1 and A2). Moreover, it has been shown that open-ocean communities support more heterotrophic biomass than do coastal communities for a given biomass of autotrophs (Gasol et al. 1997). This was clearly not the case for Stn C1, located in more oceanic waters. Actually, this station could be indicative of the earliest stages of a phytoplankton bloom, likely produced by the displacement of nutrient-rich waters from the upwelling region.

Functional indices based on intensive properties of the system, like feeding rates, should respond faster to sudden changes in primary producers than structural indices based on structural properties, like biomass (Calbet \& Alcaraz 1996). This was the case in the observed relationships between mesozooplankton ingestion rates and chl a. Although both chl a sizefractions were significantly correlated with ingestion, the regression coefficient was higher for $>5 \mu \mathrm{m}$ chl a.
This is not surprising, considering the numerical relevance of copepods in the mesozooplankton community, which are unable to feed efficiently on $<5 \mu \mathrm{m}$ prey (Hansen et al. 1994, Calbet et al. 2000a). Better relationships were apparent for ciliates, although the grazing on dinoflagellates seemed to be independent of cell concentration. In spite of the lack of relationship between dinoflagellate concentration and their consumption rates, this group was selected by mesozooplankton as a food source in preference to ciliates in some stations. It is difficult to relate these results with other studies because selectivity patterns are highly dependent on the specific communities investigated. Selection for microzooplankton over algae is not a rare feature (Stoecker \& Egloff 1987, Gifford \& Dagg 1988, Wiadnyana \& Rassoulzadegan 1989), although preference for algae over protozoans has also been observed (Williamson et al. 1996, Calbet et al. 2000a). A similar contradictory situation is found when comparing selectivity for ciliates and dinoflagellates. Dinoflagellates appear to be selected by zooplankton in some studies (Suzuki et al. 1999, present study), whereas other studies show that ciliates are the preferred prey (Stoecker \& Sanders 1985, Lonsdale et al. 2000, Vincent \& Hart-
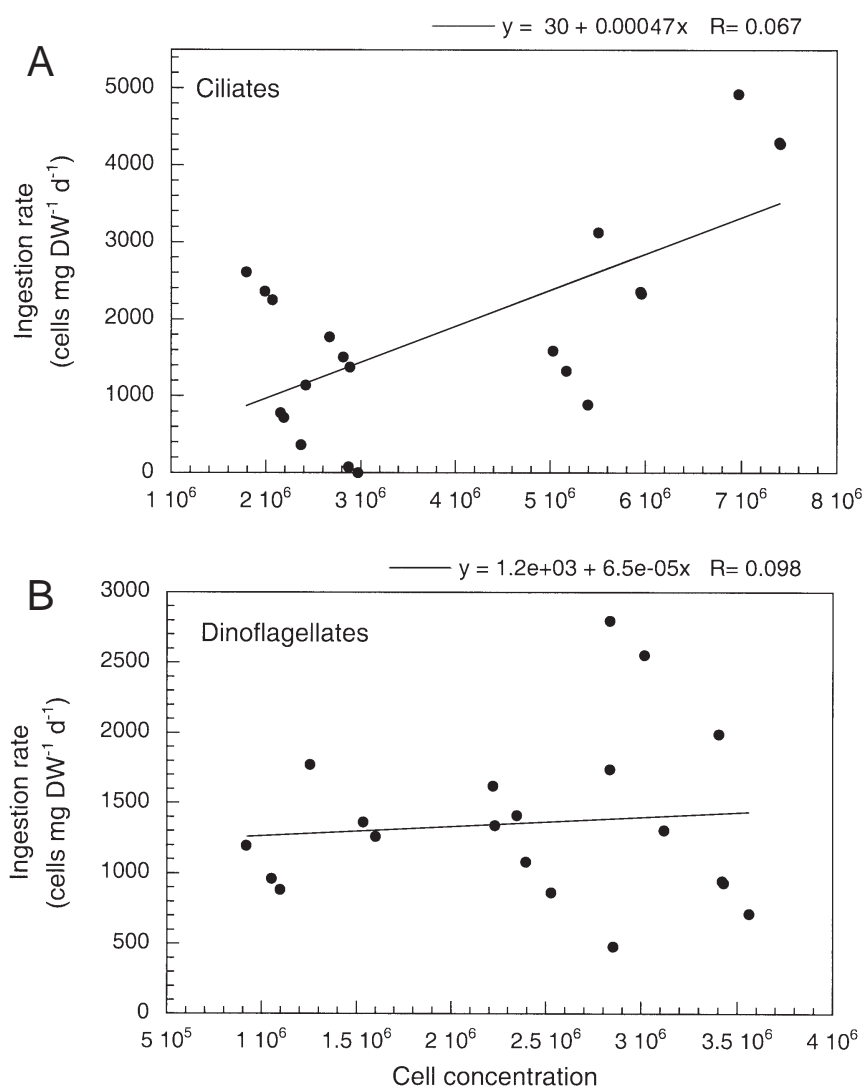

Fig. 8. Relationship between specific ingestion rates and the concentration of (A) ciliates and (B) dinoflagellates 

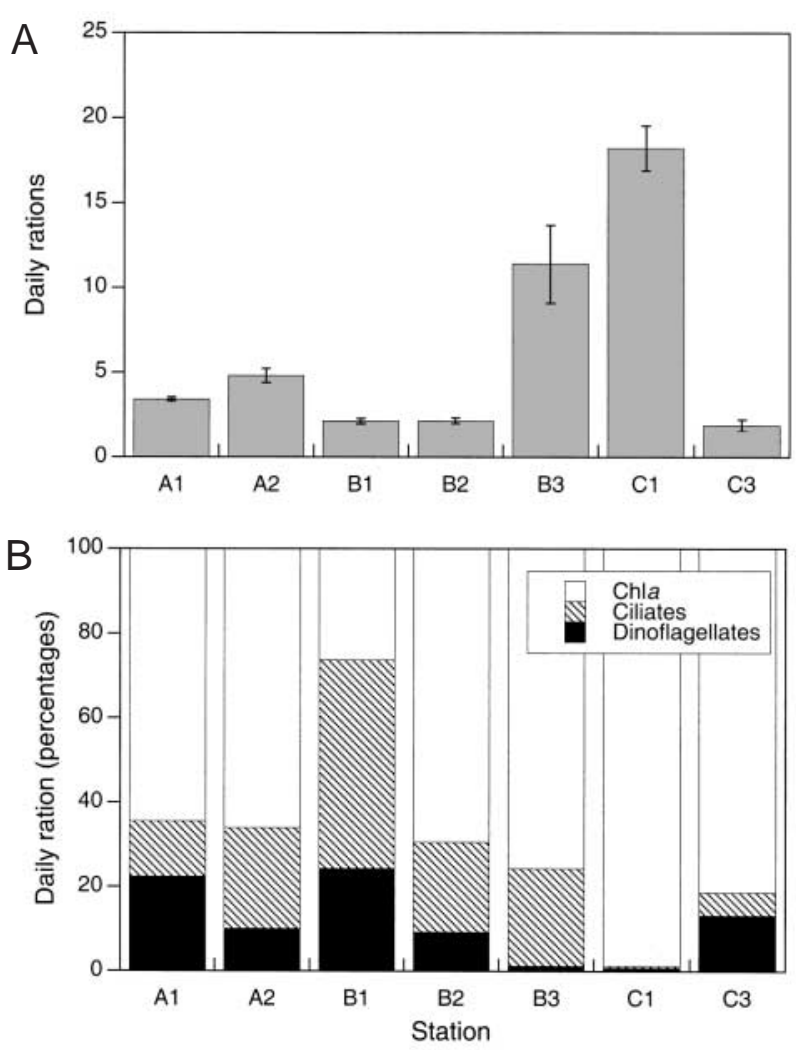

Fig. 9. (A) Total daily rations (percentage body carbon ingested daily) for the mesozooplankton of each of the stations surveyed (bars represent SE). (B) Percentage of contribution to the diet of the prey considered in the grazing experiments

mann 2001). Food-selection mechanisms are the result of complex interactions. The feeding response depends not only on the number of prey items available (Sanders \& Wickham 1993, Fessenden \& Cowles 1994) but also on the specific composition of the predators. The community found in the present study had a high proportion of cladocerans, which are believed to feed unselectively (Paffenhöfer \& Orcutt 1986). Thus, any emergent species-specific selective pattern could have been masked by the proportion of the different zooplanktonic groups in our incubations. The particular case of ciliates, which were negatively selected against dinoflagellates at some stations, could be explained by the presence in some ciliate species of escape reactions (Jonsson \& Tiselius 1990, Broglio et al. 2001), which enabled them to avoid cladoceran and copepod feeding. Aside from any electivity pattern, phytoplankton was the main food source in the daily rations of mesozooplankton (except at Stn B1). Certainly, autotrophic organisms dominated microplankton in terms of biomass. Hence, it seems quite reasonable to assume that zooplankton take advantage of the most common prey, as has been shown in other studies during phytoplank- ton bloom conditions (Tiselius 1989, Fessenden \& Cowles 1994). It is very surprising, however, that mesozooplankton daily rations and the resulting grazing impact were very low. For similar values of chl a in the same area Calbet et al. (2000b) reported copepod daily rations ranging from 20 to $50 \%$ body carbon as derived from egg production rates (assuming a gross growth efficiency of 20 to $30 \%$; Straile 1997). The daily rations found in the present study averaged $6.3 \pm 2.4$ standard error (SE), a range of 2 to $20 \%$ body carbon, which would seem barely to cover their metabolic demands. An average zooplankter of the study area (0.0089 mg DW ind. ${ }^{-1}$, Table 1$)$ would require about $4 \%$ of its body carbon to compensate for respiratory losses (Omori \& Ikeda 1984, Ikeda 1985). Only in Stns B3 and C1 was this threshold clearly surpassed, the mesozooplanktonic community experiencing severe starvation at the other stations. The low mesozooplankton ingestion rates when food was sufficiently
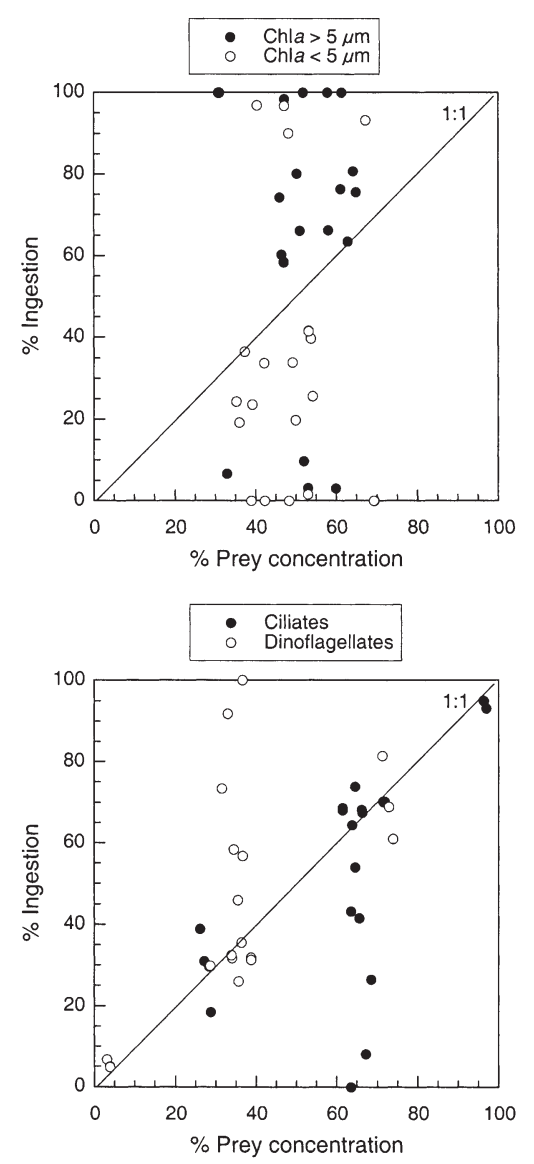

Fig. 10. Scatterplot of the percentage of a specific prey biomass in the planktonic community versus the percentage of the same prey in the total mesozooplankton carbon ingestion. Values above the 1:1 line indicate feeding selection for that prey 
abundant could be explained by the use of food sources other than the ones considered in this work (metazoan organisms, bacterioplankton or detritus). Metazoans (e.g., nauplii and copepodites) may have occasionally been ingested by some zooplankters. However, the community that dominated during our study (mostly Penilia avirostris and fine particle feeding copepods) can hardly use metazoans as their main prey item. Aggregated bacterioplankton, on the other hand, is a frequent component of the diet of cladocerans, but this is not the case for free-living bacteria (Turner 1988). Copepods are not able to exploit this food source either (Berggreen et al. 1988, Calbet et al. 2000a). In any case, at least autotrophic bacteria were already considered within chl $a<5 \mu \mathrm{m}$ estimations in our study. Detritus, which can be used as food by many zooplankters (Heinle et al. 1977, Rudstam et al. 1989, Finenko \& Romanova 1991), are only important food sources in estuarine and enclosed environments.

An alternative explanation for the low feeding rates detected during our study is related to the presence of toxic phytoplankton. The toxic dinoflagellate Gymnodinium catenatum, previously reported in the area (Delgado 1990), was present at all stations, although not at bloom concentrations (from $2.0 \times 10^{6}$ to $1.3 \times 10^{8}$ cells $\mathrm{m}^{-2}$; Table 1). The effects G. catenatum have on other planktonic organisms are not fully understood and range from no effect upon the heterotrophic dinoflagellate Polykrikos kofoidii (Matsuyama et al. 1999) to a strong reduction in copepod naupliar activity (Bagøien et al. 1996). Although the experiments of Bagøien et al. (1996) were designed to test the effects of high dinoflagellate concentrations (175 cells ml-1 $)$, one cannot exclude the possibility that there may be effects at lower concentrations as well. If this were the case, then the presence of $G$. catenatum should help explain the observed ingestion rates. To test this hypothesis we built a multiple regression model that related the total specific ingestion rates in carbon to the biomass $\left(\mathrm{mg} \mathrm{C} \mathrm{m}^{-3}\right)$ of the different components of the planktonic community. When considering only chl $a$, ciliate and dinoflagellate concentrations, the model was only significant for $\mathrm{chl} a\left(\mathrm{R}^{2}=0.68, \mathrm{p}<0.00001\right)$. However, when the concentration of G. catenatum was included, this added a significant negative term to the model and improved the coefficient of determination $\left(R^{2}=0.75, p<0.00001\right)$, explaining a higher percentage of the variability observed. The resulting equation was as follows:

Specific ingestion rate $=-0.0029+0.0019 \times \mathrm{chl} a-$ $0.029 \times$ Gymnodinium catenatum concentration

The addition of significance in the regression model does not prove a causal effect of Gymnodinium catenatum in inhibiting mesozooplankton grazing. It does, however, reinforce the idea that toxic phytoplankton could have an effect upon food webs through mesozooplankton, even when they are not at 'bloom' concentrations. In any event, the results stress the need for complementary taxonomic studies when interpreting experimental work with planktonic communities and highlight the importance of species-specific interactions in the pelagic realm.

Acknowledgements. This work was supported by the European Union within the framework of projects MAS3-CT960051 and EVK3-1999-00072, and by the Spanish grant MAR98-0854. We are indebted to R. Retamal and C. Roldán for analyzing the samples of chlorophyll and microplankton, and to M. Delgado and J. M. Fortuño for their help in taxonomic classification and scanning electron microscopy analysis of Gymnodinium catenatum, respectively. A. Sabatés kindly processed data corresponding to the vertical profiles of temperature. We also thank the scientists and crew of the RV 'Hespérides' for their assistance during the cruise, and 2 anonymous reviewers for their helpful comments and suggestions. Fig. 1 was kindly provided by X. A. G. Morán, and CTD temperature data were processed by A. Sabatés.

\section{LITERATURE CITED}

Bagøien E, Miranda A, Reguera B, Franco JM (1996) Effects of two paralytic shellfish toxin producing dinoflagellates on the pelagic harpacticoid copepod Euterpina acutifrons. Mar Biol 126:361-369

Berggreen U, Hansen B, Kiørboe T (1988) Food size spectra ingestion and growth of the copepod Acartia tonsa during development: implications for determination of copepod production. Mar Biol 99:341-352

Broglio E, Johansson M, Jonsson PR (2001) Trophic interaction between copepods and ciliates: effects of prey swimming behavior on predation risk. Mar Ecol Prog Ser 220:187-199

Calbet A (2001) Mesozooplankton grazing impact on primary production: a global comparative analysis. Limnol Oceanogr 46:1824-1830

Calbet A, Landry MR (1999) Mesozooplankton influences on the microbial food web: direct and indirect trophic interactions in the oligotrophic open ocean. Limnol Oceanogr 44:1370-1380

Calbet A, Alcaraz M, Saiz E, Estrada M, Trepat I (1996) Planktonic herbivorous food webs in the Catalan Sea (NW Mediterranean): temporal variability and comparison of indices of phyto-zooplankton coupling based in state variables and rate processes. J Plankton Res 18:2329-2347

Calbet A, Landry MR, Scheinberg RD (2000a) Copepod grazing in a subtropical bay: species-specific responses to a midsummer increase in nanoplankton standing stock. Mar Ecol Prog Ser 193:75-84

Calbet A, Trepat I, Arin L (2000b) Naupliar growth versus egg production in the calanoid copepod Centropages typicus. J Plankton Res 22:1393-1402

Carrick HJ, Fahnenstiel GL, Stoemer EF, Wetzel RG (1991) The importance of zooplankton-protozoan trophic couplings in Lake Michigan. Limnol Oceanogr 36:1335-1345

Coste B, Le Corre P, Minas HJ (1988) Re-evaluation of the nutrient exchanges in the Strait of Gibraltar. Deep-Sea Res 35:765-775 
Delgado M (1990) Phytoplankton distribution along the Spanish coast of the Alboran Sea. Sci Mar 54:169-178

Delgado M, Alcaraz M (1999) Interactions between red tide microalgae and herbivorous zooplankton: the noxious effects of Gyrodinium corsicum (Dinophyceae) on Acartia grani (Copepoda: Calanoida). J Plankton Res 21:2361-2371

Ederington MC, McManus GB, Harvey HR (1995) Trophic transfer of fatty acids, sterols, and a triterpenoid alcohol between bacteria, a ciliate, and the copepod Acartia tonsa. Limnol Oceanogr 40:860-867

Fessenden L, Cowles TJ (1994) Copepod predation on phagotrophic ciliates in Oregon coastal waters. Mar Ecol Prog Ser 107:103-111

Finenko GA, Romanova ZA (1991) The feeding and survival of the Black Sea copepod Acartia clausi Giesbr on detritus. Ehkol Morya 38:55-60

Frost BW (1972) Effects of size and concentration of food particles on the feeding behavior of the marine planktonic copepod Calanus pacificus. Limnol Oceanogr 17:805-815

García A, Camiñas JA (1985) Coastal variability of zooplankton biomass in the northwestern sector of the Albora Sea. Rapp Comm Int Mer Méditerr 29:309-310

Gasol JM, del Giorgio PA, Duarte CM (1997) Biomass distribution in marine planktonic communities. Limnol Oceanogr 42:1353-1363

Gifford DJ, Dagg MJ (1988) Feeding of the estuarine copepod Acartia tonsa Dana: carnivory vs herbivory in natural microplankton assemblages. Bull Mar Sci 43:458-468

Hansen B, Bjoernsen PK, Hansen PJ (1994) The size ratio between planktonic predators and their prey. Limnol Oceanogr 39:395-403

Heinle DR, Harris RP, Ustach JF, Flemer DA (1977) Detritus as food for estuarine copepods. Mar Biol 40:341-353

Ikeda $T$ (1985) Metabolic rates of epipelagic marine zooplankton as a function of body mass and temperature. Mar Biol 85:1-11

Jiménez F, Rodríguez J, Bautista B, Rodríguez V (1987) Relations between chlorophyll, phytoplankton cell abundance and biovolume during a winter bloom in Mediterranean coastal waters. J Exp Mar Biol Ecol 105:161-173

Jonsson PR, Tiselius P (1990) Feeding behaviour, prey detection and capture efficiency of the copepod Acartia tonsa feeding on planktonic ciliates. Mar Ecol Prog Ser 60:35-44

Klein Breteler WCM, Schogt N, Baas M, Schouten S, Kraay GW (1999) Trophic upgrading of food quality by protozoans enhancing copepod growth: role of essential lipids. Mar Biol 135:191-198

Kleppel GS, Burkart CA (1995) Egg production and the nutritional environment of Acartia tonsa: the role of food quality in copepod nutrition. ICES J Mar Sci 52:297-304

Leakey RJG, Burkill PH, Sleigh MA (1994) A comparison of fixatives for the estimation of abundance and biovolume of planktonic ciliate populations. J Plankton Res 16:375-389

Lonsdale D, Caron DA, Dennett MR, Schaffner R (2000) Predation by Oithona spp on protozooplankton in the Ross Sea, Antarctica. Deep-Sea Res II 47:3273-3283

Matsuyama Y, Miyamoto M, Kotani Y (1999) Grazing impacts of the heterotrophic dinoflagellate Polykrikos kofoidii on a bloom of Gymnodinium catenatum. Aquat Microb Ecol 17: 91-98

Menden-Deuer S, Lessard EJ (2000) Carbon to volume relationships for dinoflagellates, diatoms, and other protist plankton. Limnol Oceanogr 45:569-579

Minas HJ, Coste B, Le Corre P, Minas M, Raimbault P (1991) Biological and geochemical signatures associated with the water circulation through the Strait of Gibraltar and in the western Alboran Sea. J Geophys Res 96:8755-8771
Morán XAG, Estrada M (2001) Short-term variability of photosynthetic parameters and particulate and dissolved primary production in the Alboran Sea, SW Mediterranean. Mar Ecol Prog Ser 212:53-67

Nakamura Y, Turner JT (1997) Predation and respiration by the small cyclopoid copepod Oithona similis: how important is feeding on ciliates and heterotrophic flagellates? J Plankton Res 19:1275-1288

Omori M, Ikeda T (1984) Methods in marine zooplankton ecology. John Wiley and Sons, New York

Paffenhöfer GA, Orcutt JD Jr (1986) Feeding growth and food conversion of the marine cladoceran Penilia avirostris. J Plankton Res 8:741-754

Perkins H, Kinder T, La Violette P (1990) The Atlantic inflow in the western Alboran Sea. J Phys Oceanogr 20:242-263

Putt M, Stoecker DK (1989) An experimentally determined carbon:volume ratio for marine 'oligotrichous' ciliates from estuarine and coastal waters. Limnol Oceanogr 34: 1097-1103

Rodríguez J, Blasco JM, Jiménez-Gómez F, Echevarría F and 5 others (1998) Patterns in the size structure of the phytoplankton community in the deep fluorescence maximum of the Alboran Sea (southwestern Mediterranean). DeepSea Res I 45:1577-1593

Rudstam LG, Danielsson K, Hansson S, Johansson S (1989) Diel vertical migration and feeding patterns of Mysis mixta (Crustacea, Mysidacea) in the Baltic Sea. Mar Biol 101:43-52

Sanders RW, Wickham SA (1993) Planktonic protozoa and metazoa: predation, food quality and population control. Mar Microb Food Webs 7:197-223

Sherr E, Sherr B (1988) Role of microbes in pelagic food webs: a revised concept. Limnol Oceanogr 33:1225-1227

Sherr EB, Sherr BF, Paffenhöfer GA (1986) Phagotrophic protozoa as food for metazoans: a 'missing' trophic link in marine pelagic food webs? Mar Microb Food Webs 1: $61-80$

Stoecker DK, Egloff DA (1987) Predation by Acartia tonsa Dana on planktonic ciliates and rotifers. J Exp Mar Biol Ecol 110:53-68

Stoecker DK, Sanders NK (1985) Differential grazing by Acartia tonsa on a dinoflagellate and a tintinnid. J Plankton Res 7:85-100

Straile D (1997) Gross growth efficiencies of protozoan and metazoan zooplankton and their dependence on food concentration, predator-prey ratio, and taxonomic group. Limnol Oceanogr 42:1375-1385

Suzuki K, NakamuraY, Hiromi J (1999) Feeding by the small calanoid copepod Paracalanus sp on heterotrophic dinoflagellates and ciliates. Aquat Microb Ecol 17:99-103

Teegarden GJ (1999) Copepod grazing selection and particle discrimination on the basis of PSP toxin content. Mar Ecol Prog Ser 181:163-176

Thibault D, Gaudy R, Le Fevre J (1994) Zooplankton biomass, feeding and metabolism in a geostrophic frontal area (Almeria-Oran Front, western Mediterranean). Significance to pelagic food webs. J Mar Syst 5:297-311

Thouvenot A, Debroas D, Richardot M, Devaux J (1999) Impact of natural metazooplankton assemblage on planktonic microbial communities in a newly flooded reservoir. J Plankton Res 21:179-199

Tintoré J, Gomis D, Alonso S, Parrilla G (1991) Mesoscale dynamics and vertical motion in the Alborán Sea. J Phys Oceanogr 21:811-823

Tiselius P (1989) Contribution of aloricate ciliates to the diet of Acartia clausi and Centropages hamatus in coastal waters. Mar Ecol Prog Ser 56:49-56 
Turner JT (1988) The marine cladoceran Penilia avirostris and the 'microbial loop' of pelagic food webs. Limnol Oceanogr 32:245-255

Turner JT, Tester PA (1997) Toxic marine phytoplankton, zooplankton grazers, and pelagic food webs. Limnol Oceanogr 42:1203-1214

Turriff N, Runge JA, Cembella AD (1995) Toxin accumulation and feeding behaviour of the planktonic copepod Calanus finmarchicus exposed to the red-tide dinoflagellate Alexandrium excavatum. Mar Biol 123:55-64

Videau C, Sournia A, Prieur L, Fiala M (1994) Phytoplankton and primary production characteristics at selected sites in the geostrophic Almeria-Oran front system (SW Mediterranean Sea). J Mar Syst 5:235-250

Editorial responsibility: John Dolan, Villefranche-sur-Mer, France
Vincent D, Hartmann HJ (2001) Contribution of ciliated microprotozoans and dinoflagellates to the diet of three copepod species in the Bay of Biscay. Hydrobiologia 443: 193-204

Wiadnyana NN, Rassoulzadegan F (1989) Selective feeding of Acartia clausi and Centropages typicus on microzooplankton. Mar Ecol Prog Ser 53:37-45

Williamson CE, Sanders R, Moeller RE, Stutzman P (1996) Utilization of subsurface food resources for zooplankton reproduction: implications for diel vertical migrations. Limnol Oceanogr 41:224-233

Yentsch CS, Menzel DW (1963) A method for the determination of phytoplankton chlorophyll and phaeophytin by fluorescence. Deep-Sea Res 10:221-231

Submitted: July 2, 2001; Accepted: October 19, 2001

Proofs received from author(s): December 4, 2001 